\title{
The case for post-scholasticism as an internal period indicator in Medieval philosophy
}

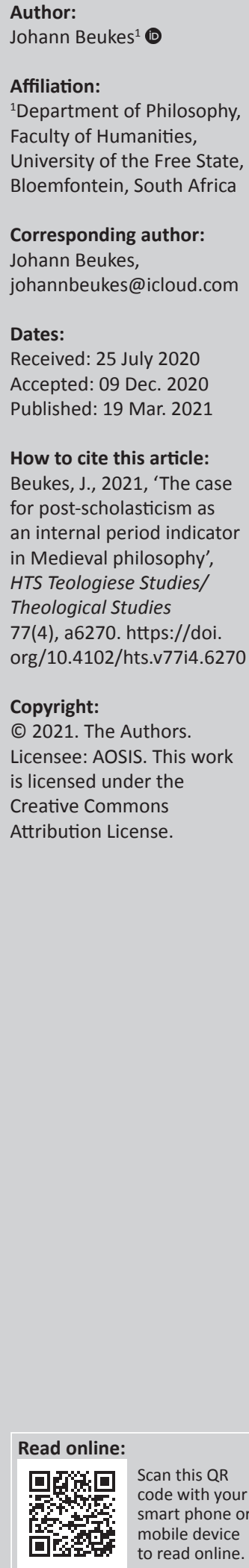

This article responds to a critical research challenge in Medieval philosophy scholarship regarding the internal periodisation of the register. By arguing the case for 'postscholasticism' as an internal period indicator (1349-1464, the era between the deaths of William of Ockham and Nicholas of Cusa), defined as 'the transformation of high scholasticism on the basis of a selective departure thereof', the article specifies a predisposition in the majority of introductions to and commentaries in Medieval philosophy to proceed straight from 1349 to 1464, understating 115 years of pertinent Medieval philosophical discourse. It is argued that in the modern account of Medieval philosophy, this understatement is manifested in either a predating of Renaissance philosophy to close the gap between 1349 and 1464 as far as possible or in proceeding straight from 1349 to Renaissance philosophy. The article presents five unique philosophical themes from this delicate period, indicating that 'post-scholasticism' was indeed a productive period in late Medieval philosophy, which should not be bypassed as an inconsequential entrance to Renaissance philosophy. The period 1349-1464 should accordingly be appreciated for its idiosyncratic contributions to the history of ideas in the late-14th and early-15th centuries, with reference to the political intensification of the via moderna, the pivotal separation of philosophy and theology and the resulting independence of the natural sciences, in res critique of institutions, transforming pragmatics and the rise of philosophical materialism.

Contribution: This article contributes to methodological development in Medieval philosophy by responding to a critical research challenge regarding the internal periodisation of the later Middle Ages. Arguing the case for 'post-scholasticism' as an internal period indicator (1349 to 1464 in Medieval philosophy, the article presents unique philosophical themes from the period, indicating that it was a productive stage in late Medieval philosophy which should not be bypassed as an inconsequential entrance to Renaissance philosophy.

Keywords: internal periodisation of Medieval philosophy; late Medieval philosophy; neo-scholasticism; orientalism in Medieval philosophy; Oxford Calculators; the problem of the 'canon' in Medieval philosophy; post-scholasticism; Renaissance philosophy.

\section{Introduction: The internal periodisation of Medieval philosophy}

The problem ${ }^{1}$ of the internal periodisation of Medieval philosophy departs from a single and rather simple question: Where does Medieval philosophy begin and end; therefore, which thinkers should be included in and which should be excluded from this discipline in the broader field of the (Western) history of ideas? This is a key question because it determines which philosophers on the margins of the historical spectrum (with Neoplatonism on the patristic left and the Italian Renaissance on the pre-modern right) belong to the corpus of Medieval philosophy. Because the developments of Neoplatonism and late-patristics towards the early Middle Ages were slow and gradual, Medieval philosophy is sometimes dated as far back and as early as Plotinus (ca. 204-270) and his counterpart Porphyreus (ca. 234 - ca. 305), while it is often dated forward and as late as the onset of the Carolingian Renaissance (742), or at least from Boethius (480-524) onwards, which, of course, certainly will exclude Augustine (354-430) from the corpus. Augustine is the pivotal figure in this internal

1.The objective of this articie is to logically and systematically disseminate the most recent specialised research concerning the period $1349-1464$, with specific reference to a philosophical exegesis of the relevant primary texts. The article is descriptive analytical in its
provision of an accessible overview of the contextual socio-intellectual history and synthetical in its aim to coherently integrate readings of the primary texts and most recent secondary texts. 
periodisation concern because it is his position that will always be in dispute in the Medieval compilation, being either the 'first Medieval philosopher' (if the argument [Beukes 2020a:I:13] that the first successful invasion of Rome in 410 designates the onset of the Middle Ages is accepted) or the vital interrelating figure from antiquity and patristics to the Middle Ages (Beukes 2012:2352). Currently, there is still no clear consensus in Medieval research about Augustine's position, either inside or outside the Medieval corpus.

The same lack of consensus is apparent in the closure of the corpus and the transition towards the Italian Renaissance: if Nicholas of Cusa (1401-1464; Beukes 2018b:1) is considered to be the 'last Medieval and first Renaissance philosopher' or perhaps the 'gatekeeper of modernity' (Gilson 1940:404), a discursive choice is thereby established, which always will have to be addressed anew. No significant progress has in any case been made over the past two decades on the possible calibration or standardisation of the dating and internal periodisation of Medieval philosophy, in the sense that Medieval philosophers are still being arbitrarily included and excluded from the corpus. In a philosophical discipline that is otherwise notoriously technical and intensely preoccupied with precision, it is curious that the dating and internal periodisation of Medieval philosophy are in the scholarship generally approached with significant laissez-faire. The author's suggestion for the internal periodisation of Medieval philosophy, in opposition to this hands-off approach, comprises the following six-part structure (for extensive argumentation, see Beukes 2020a:I:11-14): (1) the post-Roman period (5th-7th centuries [410 \{Alaric I and the first successful barbaric invasion of Rome\} to 668 \{d. Constans II\}], with Augustine [354-430] and Boethius [480-524] as the leading philosophical exponents); (2) the Carolingian period (8th and 9th centuries [742 \{b. Charles I\} to $877\{$ d. Eriugena\}], with Alcuin [730804] and Eriugena [815-877] as the leading Latin-West exponents of the Carolingian Renaissance, vis-à-vis the rise of Arabic philosophy in Baghdad and Andalusia Spain); (3) the post-Carolingian period (9th -11 th centuries [877 $\{\mathrm{d}$. Eriugena\} to 1088 \{onset of the crusades and the rise of the first universities\}], with Anselm [1033-1109] and Abelard [1079-1142] as the most influential among the Latin-West thinkers who eventually profited by the rehabilitation of antiquity in the Carolingian Renaissance); (4) the early scholastic period (12th-13th centuries [1088 ffounding of the University of Bologna, the first European university to 1225 [b. Aquinas\}]); (5) the high scholastic period (13th-14th centuries [1225 \{b. Aquinas\} to 1349 \{d. Ockham\}, with Aquinas, Duns Scotus and Ockham as the most influential among the high scholastics]) and (6) the post-scholastic period (14th-15th centuries [1349 \{d. Ockham\} to 1464 \{d. Cusa\}]). The claim to the legitimacy of the very last period in the above designation is thus under scrutiny in this article (note that the two other dominant research challenges in Medieval philosophy currently are constituted by the 'canon' in Medieval philosophy ${ }^{2}$ and the reality of a latent Orientalism ${ }^{3}$ in the discipline).

The concept 'post-scholasticism' ${ }^{4}$ is one that the author had to invent (initially for preliminary use [Beukes 2012] and

2.Specialised or niche research in Medieval philosophy undoubtedly makes the most essential contribution to the in-depth exegesis of the Medieval corpus and enables non-specialised research (which can also be called 'introduction research') to engage
the lesser known or completely unknown Medieval philosophers with some erudition. the lesser known or completely unknown Medieval philosophers with some erudition,
However, in the majority of cases, niche research is confined to the niche itself, and However, in the majority of cases, niche research is confined to the niche itself, and
the outputs from niche research remain unexpanded and unexplored in the broader the outputs from niche research remain unexpanded and unexplored in the broader
discipline of Medieval philosophy, and, of course, in the overall subject of philosophy discipline of Medieval philosophy, and, of course, in the overall subject of philosophy
itself. The severe consequence is that niche research has no impact on the established 'canon' (quotation marks henceforth omitted) of Medieval philosophy, so that the 'canon' (quotation marks henceforth omitted) of Medieval philosophy, so that the in mainstream Medieval philosophy, while the lesser known and wholly unknown thinkers are rarely enabled to penetrate the canon. The niches are generally inaccessible outside of specialist abilities and interests and are seemingly content to deliver outputs for the sake of the niches themselves, with the consequence that researchers within a particular niche only communicate with each other, and do not seem interested whether the niche is impacting the broader discipline. The challenge posed by the problem of the canon in Medieval philosophy is therefore to influence mainstream Medieval philosophy and to challenge its canon from within niche research as such. If this challenge can be progressively met, and perhaps not in the too distant future, marginal Medieval thinkers like Jean Quidort (Beukes 2019a:109-112) John of Salisbury (Beukes 2019b:1-2), Peter Damian (Beukes 2019c:1-3; 2020f:1-5) Hugo of St Victor (Beukes 2020c:262-266), Jan Van Ruusbroec (Beukes 2020d:1-4), Marsilius of Inghen (Beukes 2020e:1-4), Robert Kilwardby (Beukes 2020b:1-6) as well as female Medieval philosophers like Héloïse d'Argenteuil (Beukes 2019d:1-3) Hildegard von Bingen (Beukes 2019e:64-70) Mechtild von Magdeburg (Beukes 2019f:1-3) Marguerite Porete (Beukes 2020g:1-4) Catherine of Siena (Beukes 2019f:1-3), Marguerite Porete (Beukes 2020g:1-4), Catherine of Siena (Beukes 2020h:1-4) and Hadewijch of Antwerp (Beukes 2020i:1-3) will be as ubiquitous as their famous kindred, such as Augustine, Peter Abelard, Thomas Aquinas, Albert the Great, Bonaventure, John Duns Scotus and William of Ockham (Beukes 2020b:1-5).
The problem of the 'canon' in Medieval philosophy forms part of a much larger and The problem of the 'canon' in Medieval philosophy forms part of a much larger and
even more complex problem in contemporary science, namely the problem of hyperspecialisation. It has been argued (Beukes 2020c:270-289) that this problem can be specialisation. It has been argued (Beukes 2020c:270-289) that this problem can be
interpreted as the historical-logical consequence of the very first division of the interpreted as the historical-logical consequence of the very first division of the sciences, that is, in the strict distinction between philosophy and theology in early
scholasticism, with tempo-induced specialisation, hyper-inductive specialisation and the prioritisation of the mechanical disciplines being its evident manifestations in contemporary science.

3.The second current research problem in Medieval philosophy is determined by what can be labelled as a 'latent Orientalism' in the discipline (cf. Beukes 2018c:502-508; 2018d:565-570). Medieval philosophy is as much Occidental as it is Oriental, as much 'West' as it is 'East', and as thoroughly Latin as it is Arabic-Jewish: yet this inclusive observation is (still) absent in by far the majority of introductions to and standardised textbooks in Medieval philosophy. The Arabic and Jewish thinkers are normally sidestepped so that the homogenised index conventionally moves straight from Eriugena (815-877) to Anselm (1033-1109). Even if the reader is fortunate, only the most consequential thinkers from the Arabic-Jewish circles since Alkindi (Anno Hegirae d. ca. 256, CE ca. 801 - ca.870) are included: Ibn Sina (Avicenna, AH370 - AH428, 980-1037), Ibn Rushd (Averroes, ca. AH520 - AH595, ca. 1126$1198)$ and Moses Maimonides (1138-1204). This tendency in the discipline indicates an underlying Orientalism, meaning the discursive postulation of an 'Eastern Other' with the subtle intent to alleviate the notion of a 'Western Self'; in other words, this Orientalism points towards the apparent spontaneous acceptance of a disparity Orientalism points towards the apparent spontaneous acceptance of a disparity
between a superior Western Self and an inferior Eastern Other. Very few modern between a superior Western Self and an inferior Eastern Other. Very few moder
introductions to philosophy for the period 410 to 1464 pay attention to this introductions to philosophy for the period 410 to 1464 pay attention to this
serious methodological issue: 'East' evidently belongs to 'East', with all the pejorative undertones and editorial decisions, inclusions and exclusions, which characterise receptions from 'West to East' in modern commentaries and introductions. Should a 21 st-century reappraisal of Medieval intellectual history not at least concede that the first pursuit in antagonising such an Orientalism should at least concede that the first pursuit in antagonising such an Orientalism should register? Should there in 21st century receptions not be a more dedicated effort to register? Should there in 21st century receptions not be a more dedicated effort to
juxtapose divergent Medieval traditions - historically, ethnically, spiritually and juxtapose divergent Medieval traditions - historically, ethnically, spiritually and
linguistically - rather than subordinating one or more of these trajectories in terms of a geographical and modernist prejudice? When one subtly elaborates on the 'Arabic trajectories in Medieval philosophy' with the explicit intent to soften the hard lines between the two registers, it indeed is profitable in unmasking the persistent socio-historical prejudice in the Western register, working towards suppler hermeneutical attitude to the texts at hand; for what they are and what they represent (Beukes 2018c:539-540; 2018d:601). The undeniable fact is that at least 150 years of the history of ideas (between Eriugena and Anselm) are bypassed by this very old and established prejudice - a history of ideas which is characterised precisely by the intellectual labour of a significant number of Arabic and Jewish thinkers. It has become progressively problematic to index the Arabic thinkers of the Middle Ages in adjacent disciplines such as 'Philosophy of Islam', while the register of Medieval philosophy is then automatically composed, with few exceptions, by thinkers from the Latin West. Of course, the specialised exegesis of these Arabic thinkers still belong in sub-disciplines that can linguistically analyse the Arabic texts as such: yet these thinkers should be far more rigorously and less specialised presented in mainstream introductions to Medieval philosophy than is even still presented in mainstream introductions to Medieval philosophy than is even still currently the case. The established (Western) register of Medieval philosophy should endeavour to introduce the vast index of Medieval Arabic philosophers, which are thus effectively researched in specialised linguistic sub-disciplines, to expand that register and to work towards a single register in the discipline. Without this expansion, the Western register remains restricted, and the discursive integrity of the register will, in the author's opinion, always be under suspicion. There is still a long way to go before parity between 'East and 'West' and a single register in the discipline will finally be established: both registers should in the meantime still be enriched from their specialised or niche sources, but with the intention that both registers, in the end, be spontaneously recognised as in fact one.

4.Note that the term scholasticism is in the author's work used both as an indicator of method and a designator of period (regarding early-, high- and post-scholasticism). 
then had to employ extensively in a two-volume introduction to Medieval philosophy [Beukes 2020a:II:1175-1474]) to address a particular research concern in the field, namely to responsibly date and periodise the very last period in late Medieval philosophy, specifically not allowing it to be merged with Renaissance philosophy. This is the period between the deaths of William of Ockham (1349) and Nicholas of Cusa (1464). The question is: why is this period, consisting of 115 years, so notably understated in Medieval intellectual history, to the point of being largely absent (outside specialised research) in the Medieval register? It is indeed an awkward period, wherein the via moderna and logica modernorum took leave of the fundamental premises of the high scholasticism of the 13th century and the first half of the 14th century, thereby parting with the millennium-long development of the via antiqua et logica vetus from Augustine (354-430) and Boethius (ca. 477-524) to Anselm and Peter Abelard (1079-1142) in its development to the via moderna et logica nova, at last visible in the works of the 'last high-scholastic' Ockham and his contemporary, the 'first post-scholastic' Marsilius of Padua (1280-1343).

In answering this fundamental question regarding the understatement of the period 1349-1464, post-scholasticism can be defined as the 'transformation of high scholasticism based on a selective departure of particular aspects from high scholasticism'. This transformation of and selective departure from high scholasticism, as will be argued infra, are manifested in specific themes unique to the period: the political intensification of the via moderna (e.g. in the work of Padua), the final separation of philosophy and theology and the resulting independence of the natural sciences (e.g. in the efforts of Bradwardine and the Oxford Calculators), in res critique of institutions (as in Wyclif), transforming pragmatics (as in Biel) and the rise of philosophical materialism (as in Blasius).

A tendency in the majority of even recent introductions to Medieval philosophy will be highlighted, in terms of which the discursive space between 1349 and 1464 is circumvented by leaping straight from Ockham to Cusa, leaving behind 115 years of European intellectual history. This circumvention, on the one hand, is either grounded in a predating of Renaissance philosophy, in arbitrary attempts to minimalise the gap between the two dates, or otherwise to understate the independent status of this period between high scholasticism and Renaissance philosophy. The period is therefore often portrayed as 'intellectually unproductive' (given the enormity of the volume of conceptual outputs in high scholasticism) and 'philosophically sterile', being the 'age of the student' in opposition to the prior two scholastic periods, which are upheld as the 'age of the master'.

As a method, of which Anselm was the first exponent, 'scholasticism' refers to at least four considerations ('JWAV', Beukes 2020a:1:291-293): (1) scholastic texts are presented from the juxtaposition of ideas and texts on a particular issue; (2) the presented from the juxtaposition of ideas and texts on a particular issue; (2) the existing reception is commented on a word-by-word basis in margins and footnotes, as extensively as possible, while omissions are answered for and the Aristotelian technique of division and subdivision is adhered to; (3) Authority is established by the texts themselves and not Scripture or the confessions of the church (unless the texts are based on Scripture, of course) and (4) the legitimacy of scholastic conclusions is verified internally (in other words, not with a claim to authority external to the particular text).
}

Post-scholasticism provides an important dovetail function in the slow, transitional development from high scholasticism to Renaissance and early modern philosophy. This is not an abrupt modification and deviation of the scholastic periods, but rather a systematic one. The modern rendering of Medieval philosophy substantially evades the delicate nature of this departure from the Middle Ages in its teleological efforts to embrace the deceptive kairos of modernity and the Enlightenment. Post-scholasticism, to employ modern jargon, was neither just another dusky shadow in the 'dark ages' which had to be detoured as swiftly as possible in the distinctive leap from 1349 to 1464 , nor the last breath of scholasticism, but precisely on the basis of its selective departure from high scholasticism, the transformation thereof. The increasing non-religious accents in post-scholastic secularism, materialism and critique of institutions are what differentiate it from both high scholasticism and Renaissance philosophy. ${ }^{5}$

\section{Post-scholasticism, 1349-1464: Signals from the scholarship}

The first half of the 15th century was a period of steady intellectual development, carried forward by three centuries of scholastic labour and the progressive establishment of universities in Western Europe, such as Louvain, established in 1425. Yet, the first half of the 15th century is often (cf. Hankins 2007:33) depicted as a period of intellectual scarcity, precisely because it was not the 'age of the master' any longer (Kenny 2005:97). According to this portrayal, university lecturers (now progressively called doctores and not magistri as in scholasticism proper), instead of confronting established philosophical problems creatively and unconventionally, simply preserved the vast legacies of high scholasticism.

True as it may be in some instances, this portrayal of intellectual life in the first half of the 15th century is based on a caricaturised reception and factually not correct. In this period, there were several robust and independent philosophers stepping forward, as will be indicated infra: Padua, Bradwardine, Wyclif, Biel and Blasius, to mention a few. Furthermore, there was a tendency in the second half of the 14th century to work outside of the institutional parameters of the universities and to take leave of aspects of high scholasticism. The critique of institutions, especially

5.The author's first attempt to argue for the idea-historical importance of the period 1349-1464 eight years ago (using the Afrikaans indicator 'post-skolastiek'; cf. 1349-1464 eight years ago (using the Afrikaans indicator 'post-skolastiek'; cf.
Beukes 2012) had to be refined after the author and Jenny Pelletier, currently on the Beukes 2012) had to be refined after the author and Jenny Pelletier, currently on the
forefront of international Ockham research (see, e.g. Pelletier 2013, 2017), from the De Wulf-Mansion Centre at KU Leuven in Belgium, engaged in a productive discussion on 29 May 2019 in Louvain on the author's use of the indicator postscholasticism. The author is indebted to Professors Pelletier and Russell Friedman of $\mathrm{KU}$ Leuven for stimulating suggestions made during this audience. Following this discussion, five significant changes to the author's initial presentation in 2012 had to be made: (1) the indicator had to be properly and narrowly defined; (2) the employment of the term encyclopedic claim in this context is too robust and had to be reworked into a more subtle term, such as period-indicator; (3) the use of the term post-scholasticism must be better substantiated than it was in 2012 or term post-scholasticism discarded and replaced with a otherwise complesticator like the post-Ockham period; (4) although the five unique idea-historica developments (3.1-3.5 ifra) the author isolated coudd be far better substantiated from section than was the case in 2012; (5) only then the author's argument for the use of postscholasticism as an internal period indicator in Medieval philosophy could be regarded as consequential for the broader discipline and would justify publishing the author's case in English for the sake of argumentative clarity and accessibility. 
regarding the church, monasteries and universities, yet also the monarchy and feudal order, is precisely one feature of post-scholasticism the significance of which cannot be overstated.

It is, however, essential to note that many legacies of early and high scholasticism were still venerated into the 17th century, inter alia in the revivalist works of the Thomist, Thomas Cajetan (1469-1534) and the Iberian movement in Spain, via Francisco De Vitoria (1492-1546), Luis De Molina (1535-1600) and Francisco Suarez (1548-1617). Indeed, the last formal exponent of the Iberian movement, John of Thomas, a celebrated Thomist-scholar, died in 1644 - just 6 years before Descartes' passing. To these prolongations of scholasticism must be added Reformed scholasticism, the 17th-century Protestant version of the scholastic method, mainly via its prominent exponent Gisbertius Voetius (15891676; cf. the notable historian of Gereformeerde skolastiek, Willem Van Asselt [1996a; 1996b; 1998; 2001a; 2001b]). An intellectual tradition of more than three centuries does not disappear overnight: The discursive transition to early modern philosophy was facilitated by intersecting discourses such as post-scholasticism, Renaissance philosophy and Reformed scholasticism.

In a highly inclusive specification of the philosophical significance of the period 1349-1464, the following 37 post-Ockham philosophers were chronologically included in the authors' recent introduction to Medieval philosophy, in a section entitled straightforward as 'The post-scholastic period' (Beukes 2020a:II:1175-1474): Marsilius of Padua (1280-1343); Thomas Bradwardine (1295-1349); Jan Van Ruusbroec (1293-1381); John Buridan (ca. 1295-1361); Peter Ceffons (fl. ca. 1349); Richard Brinkley (fl. 1350-1373); Nicholas of Autrecourt (ca. 1300-1369); Robert Halifax (ca. 1300-ca. 1350); Landulph Caracciolus (d. 1351); Gregory of Rimini (ca. 1300-1358); Richard Fitzralph (ca. 1300-1360); Berthold Von Moosburg (ca. 1300-1361); Adam Wodeham (d. 1358); Richard Kilvington (1302-1361); John Dumbleton (ca. 1310-ca.1349); Ralph Strode (fl. ca. 1360-1387); William Heytesbury (ca. 1313-1372); Albert of Saxony (ca. 13201390); Nicholas Oresme (ca. 1320-1382); John Wyclif (ca. 1331-1384); Marsilius of Inghen (ca. 1340-1396); Peter of Candia (ca. 1340-1410); Hasdai Crescas (ca. 1340-1410); Blasius of Parma (1347-1416); Catherine of Siena (13471380); Peter of Ailly (ca. 1350-1420); Jean Gerson (1363-1429); Paul of Venice (1369-1429); Hieronymus of Prague (1370 1416); John Capreol (1380-1444); Paulus of Pergula (d. 1455); Cajetan of Thiene (1387-1465); Heymerik Van De Velde (1395-1460); Gabriel Biel (1408-1495); Denys De Leeuwis ('the Carthusian') (1402-1471); Peter of Rivo (1420-1500) and Nicholas of Cusa (1401-1464). It is important to note that the majority of these thinkers, in the author's analyses, were taking leave of aspects of high scholasticism while still being indebted to the basic methodological tenets thereof. It was 'not possible to break with scholasticism without the resources precisely provided by scholasticism' (Beukes 2020a:II:1174).
To justify the claim regarding the status of post-scholasticism as an internal period indicator in Medieval philosophy, yet the way this period is more often than not circumvented in Medieval research, it is crucial that the relatively recent scholarship's disposition towards the period at stake, 13491464 , be thoroughly specified. It is remarkable how often works conclude its presentation of Medieval philosophy with Ockham's death (1349): If they do provide an overview of the transition to Renaissance philosophy, the 115 years between 1349 and Cusa's death in 1464 are typically avoided (Beukes 2018:1-2).

Copleston's (1993a, 1993b) celebrated two-volume introduction, with several single-volume editions published over the preceding three decades, concludes the first volume with Duns Scotus (ca. 1266-1308) and starts the second volume with Ockham (Copleston 1993b:43-121), employing Ockham as the last important thinker of the 14th century and indeed as an entrance figure to developments towards Renaissance philosophy (1993b:275-334). Copleston in this second volume (1993b:168-206) includes five from the above list of post-scholastic thinkers, namely Marsilius of Padua (12801343), Jan Van Ruusbroec (1293-1381), Nicholas of Autrecourt (ca. 1300-1369), Denis the Carthusian (1402-1471) and Jean Gerson (1363-1429) in his discussion of developments in 1349-1464, still specified however (in the subtitle of the second volume) as 'late Medieval philosophy'. The transition from the middle of the 14th to the second half of the 15th century in Copleston's otherwise magnificent work is therefore still quite rapid: but at least this introduction acknowledges the significance of post-Ockham and pre-Renaissance developments.

Fitzpatrick and Haldane (2003:300-316) proceed from an otherwise sound explanation of the transition of the Middle Ages to modernity, straight from Ockham to Renaissance philosophy, and hence directly to the 17th-century Descartes. Overfield (1984) moves in the same direct manner from Ockham to Renaissance philosophy and early modernity, with a complete circumvention of any of the developments between 1349 and 1464. The apparent question authors like Fitzpatrick and Haldane and Overfield would pose is where such a 'post-scholasticism' should be accommodated; in other words, still in Medieval philosophy or rather and already in the Renaissance? The answer is quite simple: still in Medieval philosophy, because philosophers in the period between 1349 and 1464 were still heavily indebted to the conceptual legacies of early and high scholasticism; however, urgently, some of the thinkers listed above wanted to break with scholasticism and its institutional framework within the universities.

To refrain from the issue of periodisation altogether, focusing exclusively on thematic considerations such as in the reader of Bosley and Tweedale (eds. 2004), or otherwise providing only a conceptual introduction as in Koterski (2008), the archived discourse is tended to, but not the periodisation thereof. Even when a work stylishly eludes periodisation, as in the dignified old work of De Wulf (1907) 
or a philosopher-based work such as the excellent introduction of Pieper (2001), the archive of Medieval philosophy is addressed, yet without engaging periodisation as such. Hankins (2007:30-48), on the other hand, accentuates the prominence of Renaissance philosophy as the critical period between the Middle Ages and early modernity. This accent is, of course, understandable, given the historicalparadigmatic parameters set up by the Italian Renaissance. Still, we do not encounter an explanation of the development between the late Middle Ages and the Renaissance itself, although Hankins (2007:46-48) is subtle in his appreciation of the endurance of scholasticism, indeed until thoroughly after the Renaissance. This applies to the 17th-century revival of scholasticism, yet without reference to the preRenaissance period of 1349-1464.

Moran (2007:173) skips the period 1349-1464 altogether and presents Cusa as the essential transitional figure between the Middle Ages and modernity, focusing on the immediate preRenaissance rather than the immediate aftermath of high scholasticism, which is what post-scholasticism effectively is. Again, no account is given of the years between the deaths of Ockham and Cusa. Furthermore, Moran's position is somewhat characteristic of the predating of Renaissance philosophy often encountered in introductions, handbooks and commentaries: Instead of making the most of the period's unique contributions, there is a deliberate attempt to narrow the gap between Ockham and Cusa as far as possible, by dating the first's significance as late as possible and significantly antedating the latter's claims and development. Therefore, there is no pressure to acknowledge the discursive independence of this period between high scholasticism and the pre-Renaissance.

Colish (1999:302-318) moves straight from Ockham to a general appraisal of the legacies of scholasticism, retrospectively postulating an implicit yet decisive closure of scholasticism, and proceeds henceforth to an evaluation of scholasticism's repercussions for modern natural science, political theory and economics (pp. 319-351). A similar position is maintained by Levi (1987:103), with emphasis on the significance of scholasticism for modern humanism (Nauert's [1973:104] prior reappraisal of scholasticism focused on the same theme). Colish' gripping claim is that modernity is based far more extensively on the Medieval than the Roman inheritance. However, this daring hypothesis is not worked out sufficiently regarding the immediate aftermath of high scholasticism and what would precede early modernity. Any possible claim to postscholasticism's independence is undermined by her expressed argument for the closing of scholasticism per Ockham.

Hyman, Walsh and Williams (2010:650-707) remarkably do not end their magistral introduction to Medieval philosophy (including the Arabic-Jewish trajectories) with Ockham, but with his post-scholastic contemporary Padua. They argue explicitly (p. 252) that any closing date of (high) scholasticism in the 14th century should be considered 'arbitrary', a position maintained by the celebrated Medieval scholar, Marenbon (2007:349-352; cf. 1991:1-5; ed. 1998:1-3), who ends his introduction with a short section significantly entitled 'Not an epilogue: Medieval philosophy, 1400-1700', stating that winding-up scholasticism in the middle of the 14th century should be 'an editorial consideration' - and thus not a discursive one. Martin's (1996) riveting analysis of late Medieval philosophy echoes this 'unfinished' stance. The open-circle approach as encountered in the works of Hyman et al., Marenbon and Martin creates the possibility, if not opportunity, to explore the above 'editorial' consideration discursively from the middle of the 14th century to the middle of the 15th century: consider in this regard Clark's (1965:733) much older, inclusive appraisal of what he was still willing to refer to as 'late Medieval philosophy', thoroughly post-Ockham.

The late dating of late Medieval philosophy (and the much later transformation of scholasticism to Neoscholasticism proper) by Kretzmann (in eds. Kretzmann, Kenny \& Pinborg 1988:1-8) towards the end of the 15th century, which thus undoubtedly would have to include the full register from 1349 to 1464 , is significant. Confirmed by two late-Medieval specialists, Trentman (1988:819) and Fitzpatrick (1988:839; cf. Fitzpatrick \& Haldane 2003:315), it becomes clear that, apart from developments towards the modern era (regarding Reformed scholasticism and Neoscholasticim), a scholastic impetus is still discernible post-1349, although progressively under the guise of a selective departure from aspects of high scholasticism. That impetus forms the basis of the claim to the periodical uniqueness of post-scholasticism. Price (1992:90) notably discerns the gradual dissolution of high scholasticism in a sophisticated transition consisting of progressively non-religious intonations: this is again significant because it defines that impetus as transformational. Post-scholasticism is in this very sense, not the dying breath of high scholasticism but the conversion thereof: those 'non-religious intonations' will be indicated infra, comprise secularism, the critique of institutions, transforming pragmatics and philosophical materialism.

Equally significant is that at least some 21st-century introductions have started to move beyond Ockham as a closing figure of Medieval philosophy. The relatively recent historical dictionary of Brown and Flores ('Chronology', 2007:xix-xxxiii) includes developments after 1349 up to at least 1429 , with the deaths of Jean Gerson and Paul of Venice. The hyper-inclusive companion of Gracia and Noone (eds. 2006) covers several thinkers between 1346 and 1464 (up to even 1495), with contributions from some of the best specialists in late Medieval philosophy. Canning's (1996:135-173) analysis of Medieval political theory covers the Middle Ages up to 1450 (with a noteworthy contribution on Marsilius of Inghen [ca. 1340-1396]). Hannam's (2009) overview of the significance of Medieval philosophy for modern natural science extends the discursive effects of scholasticism well into the 16th century. Kenny's (2005) historical analysis includes Wyclif and the Oxford Calculators (54-114), Peter of Rivo (153-156) and Cusa (311-312). In its broad covering of roughly the 'period between 500 and 1500', Lagerlund's (ed. 2011:cf. its 'Preface' for the loose periodisation of the work) magnificent encyclopaedia - this 
first of its kind published in any modern language - covers the period at hand extensively. Luscombe's (2004:150-186) introduction covers several thinkers between 1349 and 1464, including Blasius of Parma, Nicholas of Autrecourt and John Buridan: In comparison, Weinberg's (1964:266) solid but dated introduction again concludes with Ockham and a few marginal notes about philosophy in the first half of the 14th century. Grant's (2004:283-355) closing chapter in his idea-historical overview of the Middle Ages focuses on the 'modern onslaught against the Middle Ages', which is a valid point, but with no bearing to the significance of the period of 1349-1464 as such. This is the trend in by far the majority of introductions up to the end of the 20th century. The extension and progressively later dating of Medieval philosophy (i.e. well post-Ockham) in the more recent works listed above opens the possibility to argue for the recognition of 'post-scholasticism' as an independent period indicator in Medieval philosophy. Five unique developments from the period 1349-1464 are henceforth presented to support this argument.

\section{Five unique developments in post-scholasticism \\ Defensor pacis: The political intensification of the via moderna}

The political philosophy of Marsilius of Padua (1280-1343) ${ }^{6}$ can be regarded as the 'perfect institutional-critical complement of Ockham's parsimony and particularising epistemological positions' (Beukes 2020a:1185). He as a result extended a political-theoretical discourse which was by the 1320 's already almost a century old. This extension contributed to the intensification of the via moderna or 'new way', as epistemologically established by Ockham. The 'new way' was initially accentuated by Emperor Frederick II (d. 1250) in his attempts to protect imperial autonomy from papal intervention by the postulation of the theory of $d u o$ regimina ('two authorities'; consisting of imperial and papal authority). The Holy Empire is accordingly completely independent and acquires its authority not from the pope, but directly from God (a Deo culmen imperii obtinemus). Both papal and imperial authority is applied in their own, distinguishable domains, and the one cannot be subordinated to the other. The one is complemented by the other in the realisation of 'different essential functions' (se ad invicem complectuntur). During the same time that Frederick II formulated the theory of duo regimina, radically new directions were developed in political philosophy, provided with impetus from the 1240s by the eventual rehabilitation and translation in Latin of Aristotle's extant oeuvre in ethics (of which political theory was considered to be part of), the progressive institutional consolidation of university structures from the late-13th century onwards and, as a logical consequence of both, increasing outputs in logic and systematic philosophy ('systematic' meaning philosophy properly distinguished from theology). After the circulation of Aquinas' celebrated De regimine principum, several political-theoretical works were presented which disseminated the theory of two authorities and attempted to stabilise it from four possible premises: the indirect or appropriated subordination of the world to the spiritual (as in Aquinas; Beukes 2020a:759), the direct subordination of the world to the spiritual and the intentional reduction of the mundane (as in Giles of Rome; Beukes 2020a:873), relative mutual independence (as in Quidort [John of Paris]; Beukes 2019a:109-121) and absolute mutual independence (as in Dante Alighieri; Beukes 2020a:983). Out of these four possible positions crystallised a single theoretical model of two coactive powers or sovereignties (which later during the Reformation would be recuperated, both by Luther and Calvin [cf. Munz 1960:156]). This is the theoretical model that Padua inherited from his political-theoretical predecessors from the late-13th century.

However, in his influential Defensor pacis, Padua (1932:III.iii) broke irrevocably with the theory of two authorities. He argues that sovereignty is singular, simple and indivisible: crucially, he stresses that sovereignty is not established in the papacy, but in humanity itself (legislator humanus; Padua 1932:1.xix.6). Defensor pacis was a radical and diverging text: everything that could be considered pertinently Medieval in high scholastic political theory, now changed. Within a decade, it became the standardised text in political theory and effectively declared the end of conventional scholastic political theory. His argument for the irreversible division of the worldly and the spiritually, thus of state and church, with a 'single sovereignty' which is to be located in the world itself - namely in the state, the civitas - represents a central and decisive feature of post-scholasticism: secularisation, which is now experienced as urgent, permanent and transformational. The work would exercise an enormous influence over the next century, not least in the political theory of Cusa himself.

Defensor pacis departed from a critique of papal intervention in the already-secularising Europe of the first half of the 14th century and introduced the profound and perpetual disunion of church and state. The endemic chaos, corruption and civil violence in the Italian social landscape of the first decades of the 14th century are depicted by Padua (1932:III.ii) as consequences both of papal arrogance and trivial political ambitions. He nevertheless moves swiftly from the local problems in Rome and the Italian city states to a more general culture-critical position with political philosophy as its basis. The state, according to Padua, is a 'perfect' society, which in its sphere is entirely independent and self-affirming. There are only two types of government: 'government by permission' (elected by the head of state's subjects) and 'government against the will' of the subjects. Only the first could ever be legitimate, while the second will always, without exception, lead to a form of tyranny. The laws of the state do not acquire its legitimacy from either the heads of state or directly from God, but from the subjects. This is a clear shift from the vertical to the horizontal, ideologically speaking. The task of legislation, in Padua's framework 
horizontal, may well be delegated to several bodies and subinstitutions, which reasonably may differ from state to state (Padua 1932:I.xix.6). The prince is merely the executive head of state: the subjects, which Padua refers to (unthinkable even two decades earlier) as 'civilians of the state', must preferably elect the prince themselves, although Padua allows for other forms of civil permission. The relevant legislation should summarily dismiss an incompetent or unstable prince.

Defensor pacis was exceptionally influential for a work which itself was still so deeply entrenched in high scholasticism: However, the work indicates a clear shift towards the seculum, in its attempt to circumvent dualistic solutions and to rehabilitate the classical notion of civitas as a single sovereignty that is established in the state itself. No representative of the Vatican was able to dismiss these claims effectively and in the long term. It provided both orthodox Catholics (at the time often accused of heresy) and 14thcentury proto-Reformers with a new theoretical basis to defend itself against the papal institution's constant intervention in public life. The via moderna has in the second half of the 14th century arrived for good.

\section{The final separation of philosophy and theology and the resulting independence of the natural sciences}

A second significant development in the middle of the 14th century was the progressive separation of philosophy and theology, within the discursive context of Padua's secularising arguments in Defensor pacis (Dolnikowski 1995:13). One movement, in particular, is to be associated with this development: the 'Oxford Calculators', initiated at the University of Oxford by Thomas Bradwardine (who died in the same year as Ockham, only months after being appointed as the archbishop of Canterbury) ${ }^{7}$ and so-called after the dissertation of Bradwardine's Oxonian colleague, Richard Swineshead (Liber Calculationem [1350]; Beukes 2020a:1131). Mirroring the separation of church and state in the unprecedented secularism of Defensor pacis, theology and philosophy are now expressly separated, while the achievements in the natural sciences contributed to its independence both from theology and Aristotelian natural philosophy (Dolnikowski 1995:14; Oberman 1963:18). As a fellow of both Balliol and Merton Colleges at Oxford, alongside Swineshead and other Merton-fellows like William Heytesbury (Beukes 2020a:1315), Bradwardine published both his two most influential works Tractatus De proportionibus ('On proportions') and Velocitatum in motibus ('On the relation of velocities in movement') in 1328, in which he theorised extensively on proportions, forces, opposition to forces and velocities. Both works were successful from the outset. They replaced Aristotle's laws of motion, which were central in causality arguments from early scholasticism onwards (already in Peter Lombard's [1095-1160] Sententiae; Beukes 2020a:419), rather abruptly. Both works were circulated with 7.See Bradwardine (1955), Dolnikowski (1995), Leff (1957:1-48) and Öberman (1963:1-23) remarkable success at the University of Paris as well. Swineshead, Heytesbury and the other Calculators played in on Bradwardine's success and produced works that were not only consequential for the expansion of natural philosophy but in its mathematical-philosophical style provided solutions for several logical and theological problems that for centuries have remained unsolved. Issues surrounding maxima, minima, differential calculus and the measurement of non-quantitative entities (such as 'warm' or 'cold', long before Celsius and Fahrenheit) were readdressed creatively and theoretically (thus without empirical support; Dolnikowski 1995:28). The consequence of these reappraisals had to be materialist, as we will see in Blasius' exposition of philosophical materialism infra.

Theoretical physics, in particular, developed swiftly and with remarkable success as an independent discipline which carried no further responsibility to theology whatsoever. Courtenay's (1987:1-11) gripping analysis of educational structures and intellectual life in England in the second half of the 14th century extensively describes this move from natural philosophy in high scholasticism to what is here referred to as 'post-scholasticism', arguing that the period 1320-1340 represents a transformational era in English scholasticism, composed of outputs by scholars such as Bradwardine, Swineshead and Heytesbury. Work performed in these two decades was consequential up to the end of the 14th century and made possible several significant shifts: moving away from characteristic Medieval school traditions in logic, mathematics and physics, the focus now was on private academic projects, bound instead to the person than the scholastic background of the academic. Levels of literacy in English society changed dramatically. For the first time (inconceivable even just three decades prior), jurisprudence drew more students than theology at Oxford. For the first time in a very long time, theology in the second half of the 14th century was not the matrix reference for all other disciplines but one who in future had to compete alongside other disciplines for a reputable position at the university. The Calculators' renewed and intense interest in logical riddles, sophismata or sophisms (so-called after Aristotle's Sophistici Elenchi), in subject terminology called insolubilia, referring to treacherous sentence structures which have to be delicately analysed in order not to lead to absurd conclusions, perpetuated the separation of philosophy and theology and facilitated the upward curve of theoretical physics. For instance, the statement 'I am lying now' is false if it true and true if it false - what does logical analysis make of this? The study of insolubilia already made up a substantial part of 13th century logic. Still, via the Calculators' 14thcentury reappraisal, it gained renewed importance in terms of the setting up of parameters for the 'new science' of the 'new way', the notion of 'modern science' in the via moderna and the reassessment of the relation between faith and science (Courtenay 1987:112; Dolnikowski 1995:121).

However, Bradwardine's contribution to the very last phase of late Medieval philosophy extended beyond the separation 
of philosophy and theology and the consequent independence of the natural sciences: he certainly still was a bona fide theologian and initiated a second development at Oxford to be carried forward towards the end of the 14th century, namely the revival of Augustinianism - after almost three centuries of intense rehabilitation, commentaries and editions of Aristotle and the Latinised reception of the Arabic Aristotelians, Ibn Sina (Avicenna) and Ibn Rushd (Averroes) in particular, without which high scholasticism would not have been possible (Beukes 2018c:1-4, 2018d:1-3). Of course, Augustine was throughout the Middle Ages an eminent presence who was not dealt with less respect than Aristotle himself. Yet neo-Augustinians like Bradwardine and the chancellor of Oxford in 1333, the Irishman Richard Fitzralph (ca. 1300-1360; Beukes 2020a:1269), reappraised Augustine precisely midst the changes that took place in post-scholastic intellectual life: There was something restrained about it, in the sense that Bradwardine anticipated that theology would have to function differently than was the case in early and high scholasticism; that theology had to be somehow protected from the consequences of the separation of theology and philosophy in post-scholasticism; that theology's patristic roots had to be rediscovered; that theology had to transform itself or otherwise be marginalised into irrelevance by the logical implications of the intensification of the via moderna. In his magistral De Causa Dei, Bradwardine accordingly presented an Augustinian review of the old logica vetus theological interests, which covered inter alia divine providence and foreknowledge, future contingents and both the notion of free will and the Augustinian prioritisation of the will over the intellect. This remarkable work, reflecting an astonishing erudition in the history of ideas, reveals an intense consciousness that an era has gone by - the age of Medieval scholasticism in general - and that a new era was dawning. This future period would more than a century later indeed be named as the 'era of rebirth' Renaissance - wherein Bradwardine's sensitivity for the reappraisal of antiquity and patristics would be imprinted. For his own era, this period profoundly departing from scholasticism, Bradwardine did not provide a name. A name that could suffice is indeed post-scholasticism. In this context, a later Oxonian, John Wyclif, deepened several of Bradwardine's via moderna inclinations.

\section{In res critique of institutions}

The life and work of the 'flower of Oxford', John Wyclif (ca. 1331-1384), ${ }^{8}$ are conventionally and correctly associated with his ultra-realism resulting in disputes with nominalism, and the theological appraisal of him as a 14th-century protoReformer. However, another profound contribution was his in res critique of institutions. Wyclif's unique Augustinianism connected him to post-scholastic predecessors like Bradwardine: unique in the sense that, unlike his predecessors, he presented a reading of Augustine which held institutional-

8.See Conti (1997.133-165: 2006:67-126) Evans (2005:1-128) Gilbert (1974:85-125), Hudson and Wilks (1987:165-177, 185-215, 217-232), Kenny , Kenny (1985:1-23, ed.1986.1-12, 2005), Lahey (2003:1-23, 2006.127-198, 2009:3-64), Larsen (2006:1-66), Michael (2003:343-360), Robson (1966:1-39), Shogimen (2006:199-240), Spade (2005:24-58), Spruyt (2008:24-58), Stacey (1964:3-48) and Wyclif (1985) critical consequences and particularly undermining implications for the church as an institution. He presented an interpretation of the Augustinian teaching on grace, elaborating on the lack of a decisive connection between God's grace and the papal institution, which lead to a posthumous conviction of determinism at the Council of Constans (1414-1418) - although he certainly was not more deterministic than Aristotelian predecessors like Aquinas or Henry of Ghent. Against the nominalistic position of Ockham, Wyclif also argued in Platonic terms that God creates by externally manifesting eternal archetypes from God's intellect so that every created substance is constituted by a universal nature and is similar to every other creature that is generically the same as the creature. From an idiosyncratic perspective, Wyclif postulates that God is not able to annihilate any individual because the annihilation of the individual would imply the annihilation of universal nature itself. That is why Wyclif was Augustinian also in the moral sense: he argues for selfless love for the other, comprising a morality which demands that the humanity in every human person is acknowledged, that the universal nature itself is an object of love and that the shared universal nature is more important than individual self-affirmation.

The separation of theology and philosophy in postscholasticism had severe implications for theologians such as Wyclif. Initiated by Padua's secularism and intensified by the Oxford Calculators, the separation of the two as distinct disciplines was, however, only formally realised during the Renaissance, with its characteristic accent on single specialisation. Not merely a theologian with an interest in philosophy but still a proper Medieval thinker in the sense that he reflected a thorough erudition in both and was not willing to subordinate the one to the other, Wyclif's technical confrontation with Ockhamism was indicative of the endurance of high scholasticism well into the late-14th century, in the sense that post-scholasticism was always still a form of scholasticism that relied on the resources of scholasticism. Yet, in the very same vein, Wyclif departed from aspects of scholasticism: he no longer conformed stylistically to the prescriptions for scholastic discourse as still was noticeable in Ockham, but presented his arguments independent from any school association as his own; he did not maintain the scholastic fixation on Aristotle and he worked unambiguously institutional-critical, following Padua. Wyclif was not squarely in scholasticism any longer, although he was epistemologically indebted to scholastic method. In that sense, he is a good example of a post-scholastic thinker.

\section{Transforming pragmatics}

The Ockhamist tradition, in all the high scholastic yet already post-scholastic characteristics thereof, did not fade away in the aftermath of Wyclif's confrontation with nominalism. It is somewhat representative of postscholasticism that it bears witness to the conflict between Ockhamism and contra-Ockhamism: a tension that fell away completely in Renaissance philosophy and thus should be sectioned in post-scholasticism. The work of the understated 
15th-century thinker Gabriel Biel (1408-1495), ${ }^{9}$ who in the last two decades of his life was already grounded in Renaissance philosophy proper, bore witness to this Ockhamist tension in post-scholasticism. Biel's work presents an integration of these two realities he was confronted with: on the one hand, the via moderna of Ockham and Padua, and on the other hand, that which succeeded the via moderna at the dawn of the Renaissance. Biel was one of the last true Ockhamists and exponents of the via moderna, yet also a selective and eclectic transformer thereof. While more 'theological' than Ockham, Biel in his epistemology nevertheless still maintained a nominalist position wherein a concrete, particularising and pragmatic approach rather than an abstract universalising one, is persistently emphasised. Theologically, his work did reveal elements that were associated (however, erroneous) with Pelagianism (Burkard 1974:12). Still, in the end, it was Ockham that provided cohesion and coherence to Biel's work: wherever Biel consulted other scholastics on themes and subjects Ockham himself did not deal with in-depth, the parameters Biel utilised to test alternatives were Ockhamist (Feckes 1925:25).

The post-scholastic quality of his work is nonetheless not to be found in a partisan dependence on Ockhamism, but rather in his attempt to synthesise competing traditions from early and high scholasticism. He covers the 'old way', the via antiqua, from Aquinas (Beukes 2020a:759) to Duns Scotus (Beukes 2020a:991), to the via moderna of Ockham, Padua, Bradwardine and Wyclif, in an eclectic, pragmatic integration of transitional thinkers such as Bonaventura (Beukes 2020a:705), which renders his work significant in an encyclopaedic sense. Yet, Biel did not only synthesise traditions, but also themes which in post-scholasticism were brought into highly problematic juxtapositions, such as knowledge and faith, and reason and spirituality - themes which in high scholasticism were rather smoothly juxtaposed (Burkard 1974:32). This pragmatic quality of Biel's work eventuated in an emphasis on social ethics and the practical implementation of theological conclusion in society itself. In this manner, Biel, in the afterglow of Padua's secularism, surveyed the prerequisites for legitimate political authority, the mutual rights and obligations of sovereignties and subjects, the morality of the papal institution and the role of money in a just economy. In other words, the pragmatic quality of Biel's work as informed by Padua's secularising activism led him to focus on social and moral issues that were

9.See Biel (1963; 1968), Burkard (1974:1-43), Clark (1965:733-765), Farthing (1988:1-81) and Feckes (1925:50-76). Biel is understated in Medieval research, precisely because of arbitrary periodisations, which always move him forward to the Renaissance corpus, as well as the Renaissance (and modern) tendency to single specialisation, which thus entrusted Biel's legacy to the theological archive. Yet, Oberman (1963) presented a thorough analysis of Biel's work in a philosophica introduction, with solid arguments as to why Biel's work still belongs in the index of Medieval philosophy. It is clear from Oberman's (1963:12) analysis that some lateMedieval philosophy. It is clear from Oberman's (1963:12) analysis that some lateMedieval thinkers such as Biel create general discomfort: they were too early for Renaissance philosophy and too late for high scholasticism. Biel, like Wyclif before him, is in this sense a prototypical post-scholastic thinker. Note that there are remarkably few noteworthy secondary texts on Biel available in English: the critica German Forschung, particularly from the Tübingen tradition, should preferably b consulted (see, e.g., Burkard 1974; Feckes 1925). Apart from Oberman's introduction, the (however, dated) article of Clark (1965) and the excellent AquinasBiel juxtaposition of Farthing (1988) can be recommended. not considered essential in high scholasticism, but only came to the fore in the via moderna from which Biel inherited it. His pragmatics are accordingly reflected in a moral activism which associates with his optimism about a 'moral potentiality' he finds in human nature (hence the accusations of Pelagianism) and which has pertinent particularising consequences for his epistemological position.

That position boils down to a focus on the ontological status of universals: via the Scotus- and Ockham-debates of more than a century earlier, Biel predictably opts for the concrete over the abstract and essentially maintains the nominalist position (Clark 1965:751). He considers universals accordingly as mere words or names that are applied ad hoc in the Aristotelian categories, while individuals are the only true existents; thus, words or names such as 'God' or 'church' have for Biel literally no meaning, unless it is lived in the pragmatics of the mundane. Biel's eclectism also takes him back to Scotus' voluntarism, in his accent on God's absolute freedom, independent of any external necessity. However, Biel radicalises the absolute nature thereof even further: In God's absolute freedom, God chooses us, but we must choose back for and towards God. Without this ready answer of the believing subject, God's election is without case or consequence. This is an essential development in the 15th century: not even Scotus' voluntarism regarding God's omnipotence would allow for such an interval, if not intervention, by the human subject (Farthing 1988:23).

Accordingly, there is a pattern of eclectic yet creative reassessments evident in Biel's pragmatism (Clark 1965:754; Farthing 1988:121). These reassessments are indeed derivatives of 15th century partisan Ockhamism: electing precisely what was necessary from scholasticism demanded much from Biel's ability to prioritise. The fact that Biel constantly actualised the scholastic legacy in moral and social terms indicates the transforming effect of his pragmatic reappraisal of scholasticism. While early scholasticism was ultra-theoretical, often to the point of complete moral and social irrelevance, high scholasticism was more open towards an account of the ethical and social implications of scholastic theorisation, with post-scholasticism intentionally and explicitly internalising these implications. This internalisation of the social and moral repercussions of scholasticism should be considered a unique feature of the latest phase of Medieval philosophy, immediately preceding the Renaissance.

\section{The rise of philosophical materialism}

The progressive independence of the natural sciences via the efforts of Bradwardine and the other Oxford Calculators led in the years between 1349 and 1464 to a dramatic development in natural philosophy, regarding the rise of philosophical materialism. Yet, it was an old dispute regarding laws of motion which deepened the 14th-century independence of the natural sciences and in post-scholasticism formally contributed to the ascent of materialism, as the most critical late-Medieval complement of modern secularism, 
rationalism, empiricism and the later development of teleological historicism. The dispute in the 1370s was absorbed by the evident inadequacy of Aristotle's law of motion, as employed by Aquinas and problematised by the Calculators. Aristotle taught that motion was caused either by an internal principle (regarding the nature of the moving object) or an external principle (regarding contact between the moving object and another object). In the latter, motion is weakened progressively by the deterioration of contact between the moving object and the other object in question. Already in the 6th century, John Philoponus (Beukes 2020a:91) refined Aristotle's dualistic law, by arguing that a moving object, when it is indeed in motion, itself possesses a force of motion or vis impressa, although vis impressa's intrinsic nature is that it weakens steadily and progressively (Schneider 1991:21). In the late-13th century, both Aristotle's and Philoponus' views were taken up by several Oxford scholars who attempted to use this (thus extended and revised) theory to explain the movement of celestial bodies. For these Oxonians, there were two possibilities: the celestial bodies are either living entities, possessing an own soul, which are kept in motion by God (an external principle). The other possibility is that the celestial bodies move naturally with vis impressa [an internal principle]. In the late-14th century, it became clear that the majority of schoolmen surprisingly sided with the latter view, with pertinent reference to vis impressa: celestial bodies were thus considered to be moving based on their mass and are kinetically independent. This position was postulated against the authoritative opinion of Aquinas, who held onto the notion of an external principle, anticipating that any position siding with the internal principle cum vis impressa would have dramatic consequences for the reception of Aristotelian natural philosophy - which is, of course, what happened: What at the zenith of high scholasticism and before the Calculators still sorted alongside mathematics and logic under the broad index of natural philosophy and would a century later be frankly referred to as the 'natural sciences', would indeed become detached from Aristotle, and Aquinas knew it (cf. Thorndike 1928:177-190).

A Franciscan contemporary of Ockham, who resided with him in Avignon before his ex-communication and subsequently fled with him to Germany, Francis of Marchia (1290-1344; Beukes 2020a:1137), theorised on the basis of the internal principle vis impressa that Aristotle's law was deficient in explaining the motion of celestial bodies, as the speed of these bodies was apparently constant, or, at least not decelerating. The internal principle vis impressa must, therefore, be extended to account for an impetus that is perpetual and not diminishing. Marchia's impetus theory, as it became known, was a startling Medieval anticipation of the 20th-century understanding that the cosmos is dynamic, that the universe expands and that the speeds of celestial bodies are not diminishing or ever constant, but indeed accelerating. The logical consequence of this 14 th-century position was that no reason exists to treat celestial bodies differently from mundane entities; that 'the things of the earth and those of the heavens are fundamentally the same' (Luscombe 2004:168). They are subordinated to the same principles of causality. This deduction was a massive leap in Medieval terms.

This intense debate, with Aquinas-loyalists on the one side and supporters of Marchia on the other, clearly was not another inner-scholastic exercise, irrelevant to those outside the schools: what was at stake was the status and implications of Medieval cosmology, astronomy and, for what it was still worth, astrology. As was the case in Biel's pragmatism, Marchia's theoretical offering now was reinterpreted in terms of its social, ethical and indeed existential consequences: if it was true that celestial bodies moved according to the internal principle cum vis impressa, and if both celestial and mundane objects are similar in their materiality and subordinated to the same principles of causality (and contingency), God can be unproblematically dismissed from theorisation on several aspects of physical reality. To what extent could this dismissal of God then be applied to the aspects of social reality? In which sense could it then be true that elements of the physical world, including societal structures, no longer required transcendent consideration or some sacramental interpretation? It was on precisely this point that Blasius of Parma (1347-1416; Blasius Parmensis; with the infamous sobriquet Doctor Diabolicus) stepped forward to propose philosophical materialism that was discursively in line with Marchian physics (cf. Biard 2009:221-234).

Predictably, the soul, as the essential substance and immortal (Platonic) form of the human subject, is rejected from this materialistic framework. The soul, according to Blasius, is a material form that should be analytically approached, explored and described - in this sense, Blasius was the Medieval frontrunner of modern psychiatry, which was developed only in the second half of the 19th century. The intellect is an organic substance and organically exposed: it grows and slows in terms of entropy, and eventually dies like any other natural phenomenon or process. The soul and the intellect can in no sense of the word be separated from the body: the soul is indeed material and therefore mortal. Blasius' teachings were disseminated and circulated with remarkable effect in the second half of the 14th century. While he would have been summarily dismissed as a heretic even only five decades prior, the formal declaration of his teachings as heresy by the bishop of Pavia in 1396 had virtually no impact on the reception and distribution of his thought. The late-14th century was geared for materialism, as it was for Padua's secularism, the independence of the natural sciences, the scholastic-independent institutional critique of Wyclif and the eclectic-transformative pragmatics of Biel.

On the one hand, philosophical materialism was characterised as 'the devil's work' (Luscombe 2004:168); on the other hand, it was clear that this devil took permanent residence. No philosophical development after Blasius could further ignore the claims of materialism, up to the point where it acquired teleological status in the dialectic-historical materialism of the 19th century. Philosophical materialism is vital in the 
argument for the periodic independence of post-scholasticism: it is clear that the context for this development was not established by high scholasticism or early Renaissance philosophy, but by the period between the two.

\section{Conclusion: The legitimate case for post-scholasticism as a period indicator in late Medieval philosophy}

This article argued the case for an independent period indicator in Medieval philosophy regarding the period 1349-1464, referred to as 'post-scholasticism'. Contra introductions to and commentaries in Medieval philosophy which leap over the period between 1349 and 1464 (the deaths of William of Ockham and Nicholas of Cusa), thus proceeding straight from Ockham to Renaissance philosophy, or predate Renaissance philosophy to close the gap between 1349 and 1464 as far as possible, or delay the dating of late Medieval philosophy as far as possible for the same reason, the article presented the period 1349-1464 as indicative of a broader problem, namely the internal periodisation of the very last part of Medieval philosophy, claiming that the period be acknowledged as an independent and legitimate internal indicator of period in the discipline (alongside five other periods summarised in the first section of the article). Named 'post-scholasticism' and defined as 'the transformation of high scholasticism on the basis of a selective departure thereof', the article henceforth presented periodisation tendencies in several acclaimed introductions to Medieval philosophy, followed by a specification of five unique philosophical themes from the period, indicating that post-scholasticism was a productive period in late Medieval philosophy, which should not be bypassed as an inconsequential entrance to Renaissance philosophy.

Post-scholasticism, the period 1349-1464, should, on basis of this presentation, be considered an independent period in the later Medieval history of ideas, with reference to the political intensification of the via moderna, the pivotal separation of philosophy and theology and the resulting independence of the natural sciences, in res critique of institutions, transforming pragmatics and the rise of philosophical materialism. That is why the indicator 'post-scholasticism' was used, for the first time, effectively and extensively, in a recent two-volume introduction to Medieval philosophy (Beukes 2020a). May this understated but important indicator slowly but surely find its way into the technical jargon of the discipline.

\section{Acknowledgements}

The author is a resident associate of the Center for the History of Philosophy and Science (CHPS) at Radboud University Nijmegen, the Netherlands.

\section{Competing interests}

The author has declared that no competing interest exists.

\section{Authors' contributions}

J.B. is the sole author of this article.

\section{Ethical consideration}

This article followed all ethical standards for a research without direct contact with human or animal subjects.

\section{Funding information}

The Department of Philosophy, Faculty of Humanities, University of the Free State, funded all page and publication fees.

\section{Data availability statement}

Data sharing is not applicable to this article as no new data were created or analysed in this study.

\section{Disclaimer}

The views and opinions expressed in this article are those of the authors and do not necessarily reflect the official policy or position of any affiliated agency of the authors.

\section{References}

Beukes, J., 2012, 'Vanaf Ockham na Kusa: Die ensiklopediese aanspraak van 'n postskolastiek in Middeleeuse filosofie', HTS Teologiese Studies/Theological Studies 68(1), Art. \#2381, 2352-2361. https://doi.org/10.4102/hts.v68i1.1134

Beukes, J., 2018a, 'n Herlesing van Pseudo-Dionisius se metafisika, HTS Teologiese Studies/Theological Studies 74(4), Art. \#5111, 1-9. https://doi.org/10.4102/hts. v74i4.5111

Beukes, J., 2018b, 'Dionisiese spore in Kusa se metafisika', HTS Teologiese Studies/Theological Studies 74(4), Art. \#5112, 1-8. https://doi.org/10.4102/hts. v74i4.5112

Beukes, J., 2018c, 'Die Arabiese trajek in die Karolingiese periode in Middeleeuse filosofie, LitNet Akademies 15(3), 502-564, viewed 24 July 2020, from https://www.litnet co.za/wp-content/uploads/2018/12/LitNet_Akademies_15-3_Beukes_502-564.pdf.

Beukes, J., 2018d, 'Die Arabiese trajek in die post-Karolingiese periode in Middeleeuse filosofie', LitNet Akademies 15(3), 565-626, viewed 24 July 2020, from https://www.litnet.co.za/wp-content/uploads/2018/12/ 24 July 2020, from https://www.litnet.co.za/w

Beukes, J., 2019a, 'De potestate regia et papali: 'n "uurglas"-bywerking van die mees onlangse Quidort-navorsing', LitNet Akademies 16(2), 109-168, viewed 24 July 2020, from https://www.litnet.co.za/wp-content/uploads/2019/10/ LitNet_Akademies_16-2_Beukes_109-168.pdf.

Beukes, J., 2019b, 'Policraticus en Metalogicon: 'n Bywerking van die Saresberiensisnavorsing, 2013-2018', Verbum et Ecclesia 40(1), Art. \#1959, 1-14. https://doi. org/10.4102/ve.v40i1.1959

Beukes, J., 2019c, “"Foucault se sodomiet”: Damianus se Liber gomorrhianus (1049) heropen', HTS Teologiese Studies/Theological Studies 75(4), Art. \#5216, 1-13. https://doi.org/10.4102/hts.v75i4.5216

Beukes, J., 2019d, 'Héloïse d'Argenteuil se filosofiese uitset', HTS Teologiese Studies/ Theological Studies 75(4), Art. \#5281, 1-12. https://doi.org/10.4102/hts. v75i4.5281

Beukes, J., 2019e, 'Hildegard von Bingen as 'n 12de-eeuse filosoof-teoloog', LitNet Akademies 16(1), 64-102, viewed 24 July 2020, from https://www.litnet.co.za/ wp-content/uploads/2019/06/LitNet_Akademies_16-1_Beukes_64-102.pdf.

Beukes, J., 2019f, “"Maak die wêreld nie tot bespotting nie”: 'n Herwaardering van die filosofiese aspekte in Mechtild von Magdeburg se Das fließende Licht der Gottheit (1250)', Verbum et Ecclesia 40(1), Art. \#1965, 1-8. https://doi.org/10.4102/ ve.v40i1.1965

Beukes, J., 2020a, Middeleeuse Filosofie, volumes I \& II, Akademia, Pretoria.

Beukes, J., 2020b, 'The Dominican Robert Kilwardby (ca. 1215-1279) as schoolman and ecclesiastical official', Verbum et Ecclesia 41(1), Art. \#2065, 1-14. https://doi. org/10.4102/ve.v41i1.2065

Beukes, J., 2020c, 'Omnium expetendorum prima est sapientia: Hugo van Saint-Viktor (1097-1141) en die probleem van hiperspesialisasie in die eietydse wetenskapsbegrip', LitNet Akademies 17(1), 262-297, viewed 24 July 2020, from https://www.litnet. co.za/wp-content/uploads/2020/04/LitNet_Akademies_17-1_Beukes_262-297.pdf.

Beukes, J., 2020d, 'Die triomf van 'n post-skolastieke mistiek oor skolastieke lojalisme: Gersonius versus Ruusbroec (postuum), 1399', HTS Teologiese Studies/Theological Studies 76(1), Art. \#5672, 1-12. https://doi.org/10.4102/hts.v76i1.5672 
Beukes, J., 2020e, "n Nijmegenaar aan die Universiteite van Parys en Heidelberg in die latere Middeleeue: Die lewe en werk van Marsilius van Inghen (ca. 1340-1396)', Verbum et Ecclesia 41(1), Art. \#2038, 1-11. https://doi.org/10.4102/ve.v41i1.2038

Beukes, J., 2020f, 'Intervroulike seksualiteit in die latere Middeleeue: 'n Ideëhistoriese oorsig', Verbum et Ecclesia 41(1), Art. \#2074, 1-13. https://doi.org/10.4102/ ve.v41i1.2074

Beukes, J., 2020g, 'Die eliminering van die siel in die filosofiese mistiek van die begyn Marguerite Porete (1250-1310)', LitNet Akademies 17(2), 204-229, viewed 24 July 2020, from https://www.litnet.co.za/die-eliminering-van-die-siel-in-die-filosofiesemistiek-en-negatiewe-teologie-van-die-begyn-marguerite-porete-1250-1310/.

Beukes, J., 2020h, 'Die "vyf trane" as mistieke uitdrukking in die Dialoë van die Dominikaanse non Katharina van Siena (1347-1380)', Litnet Akademies 17 (forthcoming).

Beukes, J., 2020i, 'The Trinitarian and Christological Minnemystik of the Flemish beguine Hadewijch of Antwerp (fl. 1240)', HTS Teologiese Studies/Theological Studies 76(1), Art. \#5865, 1-10. https://doi.org/10.4102/hts.v76i1.5865

Biard, J., 2009, 'Blasius of Parma facing atomist assumptions', in C. Grellard \& A. Robert (eds.), Atomism in late Medieval philosophy and theology, pp. 221-234 Brill, Leiden.

Biel, G., 1963, in H.A. Oberman \& W.J. Courtenay (eds.), Canonis misse expositio, volumes I-IV, Franz Steiner Verlag, Wiesbaden.

Biel, G., 1968, in H.A. Oberman, D.E. Zerfoss \& W.J. Courtenay (eds. \& transl.), Defensorium obedientiae apostolicae et alia documenta, Harvard University Press, Cambridge, MA

Bosley, R.N. \& Tweedale, M. (eds.), 2004, Basic issues in Medieval Philosophy: Selected readings presenting the interactive discourses among the major figures, Broadview Press, Ontario.

Bradwardine, T., 1955, in H.L. Crosby (intr., ed. \& transl.), Tractatus de proportionibus, University of Wisconsin-Madison, Madison, WI.

Brown, S.F. \& Flores, J.C., 2007, Historical dictionary of Medieval philosophy and theology, The Scarecrow Press, Plymouth.

Burkard, F.J., 1974, Philosophische Lehrgehalte in Gabriel Biels Sentenzenkommenta unter besonderer Berücksichtigung seiner Erkenntnislehre, Anton Hain, Meisenheim am Glan.

Canning, J., 1996, A history of Medieval political thought 300-1450, Routledge, London. Clark, F., 1965, 'A new appraisal of late-Medieval theology', Gregorianum 46(4), 733-765.

Coleman, J., 1983, 'Medieval discussions of property: Ratio and dominium according to John of Paris and Marsilius of Padua', History of Political Thought 4(2), 209-228.

Colish, M.L., 1999, Medieval foundations of the Western intellectual tradition 400-1400, Yale University Press, New Haven, CT.

Conti, A.D., 1997, Analogy and formal distinction: On the logical basis of Wyclif's metaphysics, Medieval Philosophy and Theology 6(2), 133-165. https://doi. org/10.5840/medievalpt1997627

Conti, A.D., 2006, 'Wyclif's logic and metaphysics', in I.C. Levy (ed.), A companion to John Wyclif: Late Medieval theologian, pp. 67-126, Brill, Leiden.

Copleston, F.C., 1993a, A history of philosophy volume II, Medieval philosophy, Doubleday, New York, NY.

Copleston, F.C., 1993b, A history of philosophy volume III, Medieval philosophy, Doubleday, New York, NY

Courtenay, W.J., 1987, Schools and scholars, Princeton University Press, Princeton, NJ.

De Wulf, M., 1907, Scholasticism old and new: An introduction to scholastic philosophy, Medieval and modern, Longmans, Green \& Co., London.

Dolnikowski, E.W., 1995, Thomas Bradwardine: $A$ view of time and vision of eternity in fourteenth-century thought, Brill, Leiden.

Evans, G.R., 2005, John Wyclif: Myth and reality, Intervarsity Press, Downer's Grove, IL.

Farthing, J.L., 1988, Thomas Aquinas and Gabriel Biel: Interpretations of St Thomas Aquinas in German nominalism on the eve of the Reformation, Duke University Press, Durham.

Feckes, C., 1925, 'Gabriel Biel, der erste grosse Dogmatiker der Universität Tübingen in seiner wissenschaftlichen Bedeutung', Theologische Quartalschrift 105(1), 50-76.

Fitzpatrick, P.J., 1988, 'Neoscholasticism', in N. Kretzmann, A. Kenny \& J. Pinborg (eds.), The Cambridge history of later Medieval philosophy, pp. 838-852, Cambridge University Press, Cambridge.

Fitzpatrick, P.J. \& Haldane, J., 2003, 'Medieval philosophy in later thought: The Renaissance and seventeenth century', in A.S. McGrade (ed.), The Cambridge companion to Medieval philosophy, pp. 300-316, Cambridge University Press, Cambridge.

Garnett, G., 2006, Marsilius of Padua and 'the truth of history', Oxford University Press, Oxford.

Gewirth, A., 1979, 'Republicanism and absolutism in the thought of Marsilius of Padua', Medieovo 5(1), 23-48.

Gilbert, N.W., 1974, 'Ockham, Wyclif and the, via moderna', in A. Zimmermann (ed.), Antiqui und Moderni: Traditionsbewusstsein und Fortschrittbewusstsein im späten Mittelalter, pp. 85-125, Walter de Gruyter, Berlin.

Gilson, E., 1940, The spirit of Mediaeval philosophy, Scribner, New York, NY.

Gracia, J.J.E. \& Noone, T.B. (eds.), 2006, A companion to philosophy in the middle ages, Blackwell, Oxford.

Grant, E., 2004, God and reason in the middle ages, Cambridge University Press, Cambridge.
Hankins, J., 2007, 'Humanism, scholasticism and Renaissance philosophy', in J. Hankins (ed.), The Cambridge companion to Renaissance philosophy, pp. 30-48, Cambridge University Press, Cambridge.

Hannam, J., 2009, God's philosophers: How the Medieval world laid the foundations of modern science, Icon Books, London.

Hudson, A. \& Wilks, M., 1987, From Ockham to Wyclif, Blackwell, Oxford.

Hyman, A., Walsh, J.J. \& Williams, T., 2010, Philosophy in the Middle ages: The Christian, Islamic and Jewish traditions, Hackett, Indianapolis, IN.

Kenny, A., 1985, Wyclif, Oxford University Press, Oxford.

Kenny, A., 2005, Medieval philosophy, Clarendon Press, Oxford.

Kenny, A. (ed.), 1986, Wyclif in his times, Oxford University Press, Oxford.

Koterski, J.W., 2008, An introduction to Medieval philosophy: Basic concepts, Sussex, Wiley-Blackwell, Sussex.

Kretzmann, N., Kenny, A. \& Pinborg, J. (eds.), 1988, The Cambridge history of later Medieval philosophy, Cambridge University Press, Cambridge.

Lagerlund, H. (ed.), 2011, Encyclopedia of Medieval philosophy: Philosophy between 500 and 1500 , Springer, London.

Lahey, S.E., 2003, Philosophy and politics in the thought of John Wyclif, Cambridge University Press, Cambridge.

Lahey, S.E., 2006, 'Wyclif's Trinitarian and Christological theology', in I.C. Levy (ed.), A companion to John Wyclif: Late Medieval theologian, pp. 127-198, Brill, Leiden.

Lahey, S.E., 2009, John Wyclif, Oxford University Press, Oxford.

Larsen, A.E., 2006, 'John Wyclif, ca. 1331-1384', in I.C. Levy (ed.), A companion to John Wyclif: Late Medieval theologian, pp. 1-66, Brill, Leiden.

Leff, G., 1957, Bradwardine and the Pelagians, Cambridge University Press, Cambridge.

Levi, A.H.T., 1987, 'The breakdown of scholasticism and the significance of evangelical humanism', in G.R. Hughes (ed.), The philosophical assessment of theology, pp. 101-128, Burns \& Oates, London.

Lewis, E., 1963, 'The "positivism" of Marsilius of Padua', Speculum 38(4), 541-582. https://doi.org/10.2307/2851655

Luscombe, D.E., 2004, Medieval thought, Opus-Oxford University Press, Oxford.

Marenbon, J., 1991, Later Medieval philosophy (1150-1350): An introduction, Routledge, London.

Marenbon, J., 2007, Medieval philosophy: An historical and philosophical introduction, Routledge, London.

Marenbon, J. (ed.), 1998, Medieval philosophy: Routledge history of philosophy, volume III, Routledge, London.

Martin, C.J.F., 1996, An introduction to Medieval philosophy, Edinburgh University Press, Edinburgh.

Michael, E., 2003, 'John Wyclif on body and mind', Journal for the History of Ideas 64(3), 343-360. https://doi.org/10.1353/jhi.2003.0039

Moran, D., 2007, 'Nicholas of Cusa and modern philosophy', in J. Hankins (ed.), The Cambridge companion to Renaissance philosophy, pp. 173-192, Cambridge University Press, Cambridge.

Munz, P., 1960, 'The 13th century and the ideas of Marsilius of Padua', Historical Studies 9(34), 156-172. https://doi.org/10.1080/10314616008595163

Nauert, C.G., 1973, 'The clash of humanists and scholastics: An approach to preReformation controversies', Sixteenth Century Journal 4(1), 1-18. https://doi. org $/ 10.2307 / 2539764$

Nederman, C.J., 1990, 'Medieval law and power, nature, justice and duty in the Defensor pacis: Marsiglio of Padua's Ciceronian impulse', Political Theory 18(4), 615-637. https://doi.org/10.1177/0090591790018004010

Nederman, C.J., 1991, 'Knowledge, consent and the critique of the political representation in Marsiglio of Padua's Defensor pacis', Political Studies 39(1) 19-35. https://doi.org/10.1111/j.1467-9248.1991.tb00579.x

Nederman, C.J., 1992, 'Character and community in the Defensor pacis: Marsiglio of Padua's adaptation of Aristotelian moral psychology', History of Political Thought Padua's adaptation, $377-390$.

Oberman, H., 1963, Archbishop Thomas Bradwardine: A fourteenth century Augustinian, Kemink en Zoon, Utrecht.

Overfield, J.H., 1984, Humanism and Scholasticism in late Medieval Germany, Princeton Üniversity Press, Princeton, NJ.

Padua, M., 1932, in R. Scholz (ed.), Defensor pacis, Hahn, Hanover, NH.

Padua, M., 1993, in C.J. Nederman (intr., ed. \& transl.), Marsiglio of Padua: Writings on the Empire, Defensor Minor and De translatione, Cambridge University Press, Cambridge.

Pelletier, J.E., 2013, William Ockham on Metaphysics: The science of being and God, Brill, Leiden.

Pelletier, J.E., 2017, 'Is there a metaphysical approach to the transcendentals in Ockham? The case of the Good', in J.E. Pelletier \& M. Roques (eds.), The language of thought in late Medieval philosophy: Essays in honor of Claude Panaccio, pp. 111-124, Springer, London.

Pieper, J., 2001, Scholasticism: Personalities and problems of Medieval philosophy, St Augustine Press, Chicago, IL.

Price, B.B., 1992, Medieval thought: An introduction, Blackwell, Oxford.

Robson, J.H., 1966, Wyclif and the Oxford Schools, Cambridge University Press, Cambridge.

Schneider, N., 1991, Die Kosmologie des Franciscus de Marchia: Texte, Quellen, und Untersuchungen zur Naturphilosophie des 14. Jahrhunderts, Brill, Leiden. 
Shogimen, T., 2006, 'Wyclif's ecclesiology and political thought', in I.C. Levy (ed.) A companion to John Wyclif: Late Medieval theologian, pp. 199-240, Brill, Leiden.

Spade, P.V., 2005, 'The problem of universals and Wyclif's alleged "ultrarealism"', Vivarium 43(1), 4-58. https://doi.org/10.1163/1568534054068429

Spruyt, J., 2008, 'The unity of semantics and Ontology: Wyclif's treatment of the fallacia accidentis', Vivarium 46(1), 24-58. https://doi.org/10.1163/156853408X255891

Stacey, J., 1964, John Wyclif and Reform, Westminster Press, Philadelphia, PA.

Syros, V., 2007, Die Rezeption der aristotelischen politischen Philosophie bei Marsilius von Padua: Eine Untersuchung zur ersten Diktion des Defensor pacis, Brill, Leiden.

Thorndike, L., 1928, 'Blasius of Parma (Biagio Pelacani)', Archeion 9(2-3), 177-190. https://doi.org/10.1484/J.arch.3.304

Tierney, B., 1991, 'Marsilius on rights', Journal of the History of Ideas 52(1), 5-17. https://doi.org/10.2307/2709579

Trentman, J.A., 1988, 'Scholasticism in the seventeenth century', in N. Kretzmann, A. Kenny \& J. Pinborg (eds.), The Cambridge history of later Medieval philosophy, pp. 818-837, Cambridge University Press, Cambridge.
Van Asselt, W.J., 1996a, 'Studie van de Gereformeerde scholastiek: Verleden en toekomst', Nederlands Theologisch Tijdschrift 50(1), 290-312.

Van Asselt, W.J., 1996b, 'De erfenis van die Gereformeerde scholastiek', Kerk en Theologie 47(1), 126-136.

Van Asselt, W.J., 1998, Inleiding in de Gereformeerde Scholastiek, Boekencentrum, Zoetermeer

Van Asselt, W.J., 2001a, 'Protestant scholasticism: Some methodoligical considerations in the study of its development', Nederlands Archief voor Kerkgeschiedenis, 81(3), 265-274. https://doi.org/10.1163/002820301X00013

Van Asselt, W.J., 2001b, 'Gisbertius Voetius (1589-1676): Gereformeerd scholasticus', in A. De Groot \& O.J. De Jong (eds.), Vier Eeuwen Theologie in Utrecht, pp. 99-108, Meinema, Zoetermeer

Weinberg, J.R., 1964, A Short History of Medieval Philosophy, Princeton University Press, Princeton.

Wyclif, J., 1985, in A. Kenny (transl.), P.V. Spade (intr. \& comm.), Tractatus de universalibus, Clarendon Press, Oxford. 